\title{
THE INFLUENCE OF USING PODCAST TOWARD LISTENING COMPREHENSION
}

\author{
By: \\ Nur Oktaviani \\ Universitas Muhammadiyah Metro Lampung \\ oktaani94@gmail.com \\ Fenny Thresia \\ Universitas Muhammadiyah Metro Lampung \\ fenny.thresia@yahoo.com
}

\begin{abstract}
Listening is an individual concentration on specific aspects of aural information, build context from passages, and connect what they hear to prior experience. Unfortunately, listening activities are rarely given to students. The problem is formulated as follow: "Is there any significant difference of using video podcast toward listening comprehension of students majoring in Multimedia at the first grade of SMK 4 Metro?". The research design was quasi-experimental. The students Majoring in Multimedia at first grade SMK 4 Metro as population. To assess the students' listening comprehension, the researcher used a written test. Based on the result, the significance score of 0.002 was smaller than t table 0.05 , which meant that $\mathrm{Ha}$ was accepted and there was a significant difference between students who taught by using podcast and those who were not. As a result, podcasts became an enjoyable medium to use in teaching listening skill.
\end{abstract}

Keywords: podcast, video, listening comprehension

\section{INTRODUCTION}

Some skills must be learned by

students such as listening, speaking,

writing, and reading. Among those

skills, listening should have an

essential place in teaching learning

English because it is impossible for the people to speak without listening

first.

Listening is very crucial in communicating with others. Based on Feyten in Vasiljevic (2010, p.41), listening spent more than $45 \%$ in time communication which emphasizes how essential this skill 
among overall language ability.

Besides, Spratt, Pulverness, and Williams (2005, p.31) explain that listening covers several things that deals with the spoken language characteristic, using the context and learning the world, grasping various text types, comprehending dissimilar rates of oration and accents, and employing diverse sub skills of listening.

Listening is the first skill obtained by learners and the other skills comply later (Miranty and Rachmawati, 2016). Ramli and Kurniawan (2018) also add that listening is basic in the language classroom because it offers inputs for students. It indicated that listening is a vital English skill that must be taught by the students to listen effectively and critically.
According to Rost (2002) cited in Gumilang (2019), listening is a way to achieve what the speaker says (receptive orientation); to develop and reflect the meaning (constructive orientation); discuss the meaning of the speaker and reply (collaborative orientation); and, make sense of involvement, imagination, and empathy (transformative orientation). Listeners usually connect what they have already known and what they listen to, therefore, listening seems more like an active process which is very complex.

Furthermore, students still rarely do listening activities in the classroom. Consequently, students often get difficulty listening to the English text that makes their listening skill has not improved well yet. Besides, the material of listening 
are not interesting so students are lazy to listen it carefully.

Moreover, school final examinations, university entrance examinations, and other examinations do not include listening as one of the components to be tested. That would be at least one reason why listening has not been paid much attention. If it is not tested, teachers will not pay attention to it. Another reason why listening has been ignored is that there are still people who view listening as a passive skill. It inferred that listening is rarely to be tested in the examination and neglected in the process of teaching English that made students got difficulty to comprehend listening.

To solve the listening problem, English teachers are expected to arouse the students' listening skill. In this case, English teachers can create something new in the teachinglearning process, such as using podcast videos.

According to Fox (2008), firstly, podcasts is audio files uploaded to the internet and downloaded to mobile means, for example, a cell phone, mp 3 player or iPod or just listening straight from the computer. To make audio file online becomes podcasts, it is better to subscribe so that the learners will be informed when a new episode is available and automatically can be downloaded to computer. Net it can be listened or transferred to mobile device and can be attached a video or picture. Abdulrahman, Basalama, and Widodo (2018) also describe that podcasting is an innovative mobile technology includes series video and digital audio broadcast that could be 
downloaded and performed on mobile.

Furthermore, podcasting is one

of an effective and new technological media that has been applied education for several years. Sayadi and Heidar (2018) state that by using podcasts, instructors can give learners a chance to listen to native speakers' oration. Students also generally enjoy using podcasts. Podcasts supply positive students' attitudes towards learning allowing learners to do task at their own pace and under non-threatening conditions.

\section{METHODOLOGY}

This study used the quasiexperimental method because of using two classes, namely experimental and control classes. The experimental class was given treatment, namely video podcast. The researcher chose this class as the experimental class to know the influence between control and experimental class after giving the treatment and the researcher compare result from each class. Meanwhile, the control class had no treatment.

The population was all students of Multimedia major at first-grade SMK 4 Metro. In this research, the researcher used two classes, the first class as the experimental class consisted of 32 students. The researcher chose this class as the experimental class because the student score was still low category so that the researcher gave the special treatment using video podcast. The second class was the control class consisted of 32 students and did not receive treatment. To run the data, a t-test was used. 


\section{RESULT AND DISCUSSION}

Based on the result of the experimental class, the mean score for pretest data was 67.2400 and 83.2600 for posttest. For standard deviation data of pretest was 0.42377 and 0.31024 for posttest. While the variance of pretest data was 0.180 and 0.096 for posttest.

Based on the result of the control class, the mean score for pretest data was 72.8300 and 78.9400 for posttest. For standard deviation data of pretest was 0.28614 and 0.33292 for posttest. While variance of pretest data was 0.082 and 0.111 for posttest.

Based on the result data of the independent sampe t-test showed that there was a significant difference between the experimental and the control class. It was found that the mean difference between posttest and pretest of the experimental and control classes was 4.32 at the significance of $p<0.05$. It meant that there was a significant difference between posttest in experimental class and posttest in control class. The results showed that podcasts influenced the learners' listening comprehension achievement of the experiment class. Learners' score who learned listening comprehension using podcast were better than those in the control class.

Using Podcast media, students were able to listen by themselves in order to practice listening in the class and at their home. Students also enjoy listening it because they could repeat listening it out of the class. Besides, most students were interested in using the podcasts so that they asked questions actively about listening materials that they 
never dealt with before. They also paid attention to the listening materials presented through Podcast and listened it attentively. They requested the researcher about material that they heard. Students were discipline and enthusiasm during the teaching and learning activities so that the researcher was easily to control the class, to observe them every meeting, and to check students' progress in listening comprehension. The result of this study was inline with Asmara (2017, p.108) who claims that ELT podcast boost students to learn new syllables and became more independent learners. Using ELT podcast, the teacher could monitor students at every step to obtain them to complete their work and it also increased teacher's confidence in their abilities to design meaningful activities that successfully partake students to know new words in listening comprehension class.

Furthermore, the use of Podcast assisted students to understand listening comprehension better and gave recent experience to students. Teachers in this case could use Podcast and make interesting material using various Podcast so that students could increase their listening comprehension achievement.

\section{CONCLUSION}

Podcast media gave effect on increasing the first grade students' listening achievement of the multimedia majoring at SMK 4 Metroacademic year 2017/2018. Podcasts can be used as an 
alternative media because this media

could improve the score of students

listening comprehension.

\section{REFERENCES}

Abdulrahman, T., Basalama, N., \& Widodo, M. R. (2018). The impact of podcasts on efl students' listening comprehension. International Journal of Language Education, 2(2), 23-33. Retrieved from https://doi.org/10.26858/ijole.v2 i2.5878

Asmara, R. (2017). Utilizing podcasts to develop listening comprehension. Language and Education Journal, 2(2), 99110.

Fox, A. (2008). Using Podcasts in the EFL Classroom. Tesl-Ej, 11(4), 1-11.

Gumilang, W. A. (2019). The use of Radio Podcast in teaching listening comprehension at STKIP PGRI Tulungagung. The International English Language Teachers and Lecturers Conference, 3(1), 251. Retrieved from http://ineltal.um.ac.id/wpcontent/uploads/2020/01/35Willy-Anugrah-Gumilang-TheUse-of-Radio-Podcast-inTecahing-ListeningComprehension-at-STKIPPGRI-Tulungagung.pdf
Miranty, D., \& Rachmawati, D. (2016). Designing Podcast for students: A prototype for teaching English in listening class. Journal of English Language Studies, 1(2), 105120. Retreived from https://jurnal.untirta.ac.id/index. php/JELS/article/view/961

Ramli, A. mardila, \& Kurniawan, E. hari. (2018). The use of Podcast to improve students' listening and speaking skills for EFL learners. International Conference on English Language Teaching (ICONELT 2017), 145, 189-194. Retrieved from https://doi.org/10.2991/iconelt17.2018 .42

Sayadi, M., \& Heidar, D. M. (2018). The impact of using Podcast on Iranian autonomous/non autonomous EFL learners' listening comprehension ability at pre-intermediate level. International Journal of Research in English Education, 3(3), 72-82.

Spratt, Pulverness, \& Williams. (2005). The TKT teaching knowledge test course. Cambridge: Cambridge University Press.

Vasiljevic. (2010). Dictogloss as an interactive method of teaching listening comprehension to 12 learners. Tokyo: Faculty of Literature Bunkyo University. 